\title{
Archaeological Investigations of Areas Slated for Expansion at Fort Sam Houston National Cemetery, San Antonio, Texas
}

Eric C. Gibson

Courtenay J. Jones

Dennis A. Knepper

Follow this and additional works at: https://scholarworks.sfasu.edu/ita

Part of the American Material Culture Commons, Archaeological Anthropology Commons, Environmental Studies Commons, Other American Studies Commons, Other Arts and Humanities Commons, Other History of Art, Architecture, and Archaeology Commons, and the United States History Commons

Tell us how this article helped you.

This Article is brought to you for free and open access by the Center for Regional Heritage Research at SFA ScholarWorks. It has been accepted for inclusion in Index of Texas Archaeology: Open Access Gray Literature from the Lone Star State by an authorized editor of SFA ScholarWorks. For more information, please contact cdsscholarworks@sfasu.edu. 


\section{Archaeological Investigations of Areas Slated for Expansion at Fort Sam Houston National Cemetery, San Antonio, Texas}

\section{Creative Commons License}

\section{(c) (1) (8)}

This work is licensed under a Creative Commons Attribution-NonCommercial 4.0 International License 


\title{
ARCHAEOLOGICAL INVESTIGATIONS OF AREAS SLATED FOR EXPANSION AT
}

\section{FORT SAM HOUSTON NATIONAL CEMETERY, SAN ANTONIO, TEXAS}

\author{
ERIC O. GIBSON. \\ COURTENAY J. JONES. \\ AND DENNIS A. KNEPPER
}

CENTER FOR ARCHAEOLOGICAL RESEARCH THE UNIVERSITY OF TEXAS AT SAN ANTONIO ARCHAEOLOGICAL SURVEY REPORT, NO. 119 1982 





\author{
ARCHAEOLOGICAL INVESTIGATIONS OF \\ AREAS SLATED FOR EXPANSION AT \\ FORT SAM HOUSTON NATIONAL CEMETERY, \\ SAN ANTONIO, TEXAS
}

\author{
PROJECT PERFORMED FOR \\ THE NATIONAL PARK SERVICE, SOUTHWEST REGION \\ UNDER PURCHASE ORDER PX 7029-2-0264 \\ WITH FUNDS PROVIDED BY THE VETERANS ADMINISTRATION
}

Eric C. Gibson, Courtenay J. Jones, and Dennis A. Knepper

Center for Archaeological Research The University of Texas at San Antonio Archaeological Survey Report, No. 119 



\begin{tabular}{|c|c|}
\hline \begin{tabular}{|l|l|l|} 
BIBLIOGRAPHIC DATA & '. Repor WOa & 2 \\
SHEET.
\end{tabular} & 3. Kesipient's Accessuion Na \\
\hline \multirow{2}{*}{$\begin{array}{l}\text { Archaeological Investigations of Areas Slated for Expansion } \\
\text { at Fort. Sam Houston National Cemetery, San Antonio, Texas }\end{array}$} & $\begin{array}{l}\text { S. Report Date } \\
\text { September } 1982\end{array}$ \\
\hline & $\sigma_{*}$ \\
\hline $\begin{array}{l}\text { 7. Aurhor(s) } \\
\text { Eric C. Gibson, Courtenay J. Jones, and Dennis A. Knepper }\end{array}$ & $\begin{array}{l}\text { 8. Periormiag Organizasion Rept. } \\
\text { No. ASR } 119 \\
\end{array}$ \\
\hline \multirow{2}{*}{$\begin{array}{l}\text { 9. Performing Organizasion Name aldress } \\
\text { Center for Archaeological Research } \\
\text { The University of Texas at San Antonio }\end{array}$} & 10. Projeez/Take/Work Unir No. \\
\hline & $\begin{array}{l}\text { 71. Concraces Grane No. } \\
\text { PX 7029-2-0264 }\end{array}$ \\
\hline \multirow{3}{*}{$\begin{array}{l}\text { 12. Sponsoring Ongaization Nam and Addreas } \\
\text { United States Department of the Interior } \\
\text { The National Park Service, Southwest Region } \\
\text { Santa Fe, New Mexico }\end{array}$} & 13. Irpa of Repors \& Period \\
\hline & Survey $4-5-82--4-9-82$ \\
\hline & 14 \\
\hline
\end{tabular}

L. Supplementary Notes

16. sbarsets During April 1982, archaeologists from the Center for Archaeological Research at The University of Texas at San Antonio conducted a cultural resource survey and evaluation of 31.68. acres slated as an expansion area for the Fort Sam Houston National Cemetery in San Antonio, Texas. This was accomplished through two research methods:

(1) a literature and archival search supplemented by interviews of knowledgeable persons; followed by (2) a planned subsurface archaeological testing program. One badly disturbed prehistoric site (41 BX 346) of unknown function and unknown chronological association was discovered as a result of these activities. Because the site is. so severely mixed and displaced, it is not considered a significant cultural resource, and no further work is recommended. The legal basis for this cultural resource survey and evaluation is described in the federal legislation of the National Historic Preservation Act of 1966, as amended, the Archeological and Historical Preservation Act of 1974, and Executive Order 11593.

17. Kay Words and Docunas Aadyase. 176 Descriprers

Cultural Resource Survey

Bexar County

Archaeology

South Texas

17b. Idemitiers/Opeanended Term

17e. COSATI Field.'Group

\begin{tabular}{|c|c|c|}
\hline \multirow[t]{2}{*}{ 18. Arallabliticy stacemene } & $\begin{array}{l}\text { 79. Securisy Class (This } \\
\text { Repom) } \\
\text { UNC, AsSIFIrn }\end{array}$ & $\begin{array}{c}\text { 21. Yo. af Pages } \\
44\end{array}$ \\
\hline & 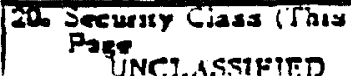 & 22 Price \\
\hline
\end{tabular}




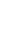




\section{FOREWORD}

Archaeological and archival research carried out by the Center for Archaeological Research, The University of Texas at San Antonio, during Apri1 1982 at Fort Sam Houston National Cemetery, discovered one prehistoric site (41 BX 346). This research was conducted at the request of the National Park Service, Southwest Region, under Purchase Order PX 7029-2-0264 with funds provided by the Veterans Administration.

Eric C. Gibson directed the field work and analysis, with the assistance of Center staff members, Courtenay J. Jones and Dennis A. Knepper. This monograph presents the results of the field work and the analytical activities that followed. This project represents a contribution to our understanding of prehistoric settlement patterns in south Texas and additionally documents the historical land use patterns of the study area.

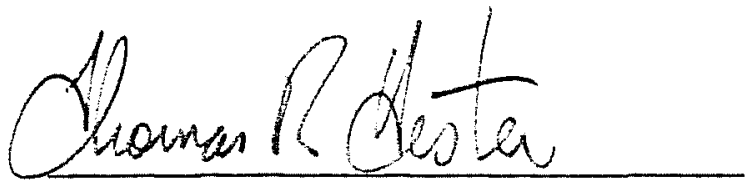

Thomas R. Hester

Principal Investigator 


\section{ABSTRACT}

During Apri1 1982, archaeologists from the Center for Archaeological Research at The University of Texas at San Antonio conducted a cultural resource survey and evaluation of 31.68 acres slated as an expansion area for the Fort Sam Houston National Cemetery in San Antonio, Texas. This was accomplished through two research methods: (1) a literature and archival search supplemented by interviews of knowledgeable persons; followed by (2) a planned subsurface archaeological testing program. One badly disturbed prehistoric site (41 BX 346) of unknown function and unknown chronological association was discovered as a result of these activities. Because the site is so severely mixed and displaced, it is not considered a significant cultural resource, and no further work is recommended. The legal basis for this cultural resource survey and evaluation is described in the federal legislation of the National Historic Preservation Act of 1966, as amended, the Archeological and Historical Preservation Act of 1974, and Executive Order 11593. 
Foreword ....................... i

Abstract .............................. i

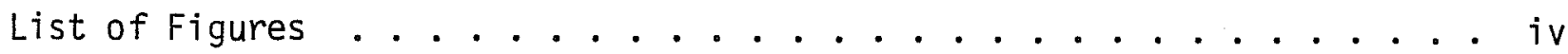

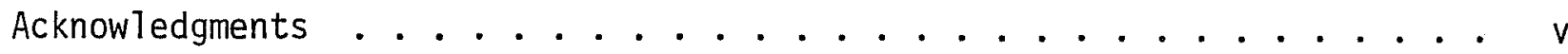

Introduction ....................... 1

Previous Archaeological Research ................. 2

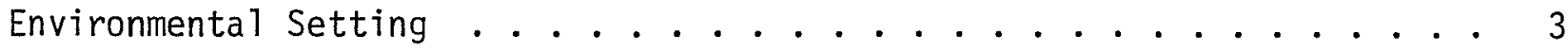

Physiography .................. 3

Geology .................... . . 3

Geomorphology ................... . . 4

Local Environmental History . . . . . . . . . . . . . . . 4

Local Vegetation and Fauna .............. . 4

The Chronology of Prehistoric 0ccupation .............. 5

Historic Use of the Study Area . . . . . . . . . . . . . . 5

The Project Investigations . . . . . . . . . . . . . . 8

Methods .................... . . 8

Artifact Terminology ............... 9

Description of Backhoe Test Units . . . . . . . . . . 10

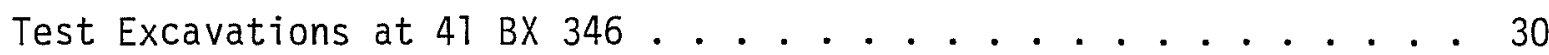

Summary of Subsurface Investigations . . . . . . . . . . . 34

Recommendations .................. 34

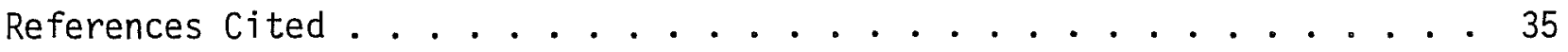




\section{LIST OF FIGURES}

Page

1. Location for Backhoe Test Units and Test Pits for 41 BX 346 . . . 6

2. Profile of Backhoe Test Unit 14 ............. 18 


\section{ACKNOWLEDGMENTS}

Mr. Thomas Costanzo, Director, and Mr. Mac Cochenour, Deputy Director, of the Fort Sam Houston National Cemetery provided valuable information and contacts on the Post. We are grateful for their help. We also appreciate the interest and assistance of Stephanie Rodeffer of the National Park Service, who administered the project. Great help was also provided by Mr. John M. Manguso, Curator of the Fort Sam Houston Military Museum, who generously furnished unpublished information and photographs from the museum archives.

Finally, we wish to thank Dr. Thomas R. Hester, Director, and Mr. Jack Eaton, Associate Director, of the Center for Archaeological Research at The University of Texas at San Antonio, for their encouragement and supervision throughout al1 aspects of this project. 


\section{INTRODUCTION}

During April 1982, archaeologists from the Center for Archaeological Research (CAR), The University of Texas at San Antonio (UTSA), carried out a cultural resource survey including subsurface testing and evaluation of 31.68 acres of land at the Fort Sam Houston National Cemetery in San Antonio, Texas. The study area is on the Fort Sam Houston Military Reservation and is adjacent to the east side of the National Cemetery. This area is the proposed location for future cemetery enlargement. The legal basis for this cultural resource survey and evaluation is described in the federal legislation of the National Historic Preservation Act of 1966, as amended, the Archeological and Historical Preservation Act of 1974, and Executive Order 11593.

The project was conducted under an order (No. PX 7029-2-0264) from the National Park Service, Southwest Region, Albuquerque, New Mexico. Dr. Stephanie $H$. Rodeffer served as the Project Manager. The objective of the cultural resource survey was to determine if any significant cultural resources were in the study area. This was accomplished through two research methods: (1) a literature and archival search supplemented by interviews of knowledgeable persons who provided historical data; this was followed by (2) a planned subsurface archaeological testing program. At the request of Dr. Rodeffer, extensive testing was done.

The project field work began with a visit to the Fort Sam Houston National Cemetery Headquarters. Mr. Thomas Costanzo, the Director, and Mr. Mac Cochenour, the Deputy Director were consulted and informed of the research plans. Mr. Cochenour drove the author to appropriate facilities (the Engineering office, the post museum, etc.,) where maps and pertinent documents were obtained. Mr. John M. Manguso, Curator of the Fort Sam Houston Military Museum was interviewed and provided a great deal of unpublished information concerning the historical land use of the study area. Much of the historical data presented in this report are derived from the museum archives.

The records of the CAR were also checked during this initial phase of the project. The field notes and documents of the CAR 1977 Fort Sam Houston Project (Gerstle, Kelly, and Assad 1978) and the nearby John James Park Project (Frkuska et al. 1977; Katz 1977), were reviewed in detai1.

Additionally, the Texas Historical Commission was contacted to ascertain if any historic places in the study area were listed with or eligible for, the National Register of Historic Places. No such designations had been made within the study area, although the Fort Sam Houston National Cemetery has been determined to be eligible for inclusion in the National Register of Historic Places.

\section{PREVIOUS ARCHAEOLOGICAL RESEARCH}

The study area is drained by an intermittent stream that joins the Salado Creek approximately $700 \mathrm{~m}$ to the south. There are no known sites within the project area but the Salado Creek watershed has been the focus of many recent archaeological studies in Bexar County (Scurlock and Hudson 1973; Hester et al. 1974; Hudson, Lynn, and Scurlock 1974; Frkuska et al. 1977; Katz 1977; Fox 1977; McGraw, Valdez, and Cox 1977; Gerstle, Kel1y, and Assad 1978; Black and McGraw 1982). 
Most of these projcts were located in the Upper Salado drainage; that area north of the intersection of Salado Creek and the Austin Highway in San Antonio (see Frkuska et al. 1977; Katz 1977; Fox 1977; Gerstle, Kel1y, and Assad 1978 for exceptions). The two reasons why the drainage is divided at this location is that all of the confluences of the major tributaries of the Salado creek are north of this boundary, and the soils change from the thin calcareous soils of northern Bexar County to the deep clayey soils common in eastern and southern Bexar County (Black and McGraw 1982). Black and McGraw's (1982) study of the Panther Springs site contains the best available summary of the archaeology of Salado creek. One of the findings of their study was that, within the Upper Salado watershed, close proximity to sources of water (i.e., springs and creeks) was a major factor influencing the location of large prehistoric occupation sites. Additionally, Black and McGraw demonstrated that these sites were most numerous in the southern portion of the Upper Salado drainage. This area marks the southern extent of the central Texas prehistoric cultural area. South of this area (i.e., the Lower Salado) archaeological materials more closely resemble the south Texas archaeological region. Research as extensive as the Black and McGraw study has not yet been attempted for the Lower Salado.

Many of the sites that have been discovered along the Lower Salado have been located close to the creek. However, this may be a factor of archaeological sampling bias. The two largest occupation sites in the vicinity of the study area, 41 BX 194 and 41 BX 305, are located adjacent to Salado Creek (Frkuska et al. 1977; Katz 1977; Gerstle, Kelly, and Assad 1978). An extensive terrace site, 41 BX 194, was obliterated by construction of the golf course at Fort Sam Houston (Gerstle, Kelly, and Assad 1978). Before it was destroyed the site was reported to contain in situ hearths, burned rock scatters, extensive lithic scatters, and faunal materials (Thomas R. Hester, personal communication). Artifacts collected in 1974 (Gerstle, Kel1y and Assad 1978:313) included Middle and Late Archaic specimens (Abasolo and Tortugas projectile points) as wel1 as Late Prehistoric materials (bone-tempered ceramics, Scallorn and Perdiz arrow points).

Subsurface testing at 41 BX 305 indicated that it functioned as a camp site during the Middle Archaic period (Katz 1977:11). A large number of cutting and piercing tools showed evidence of faunal butchering activities. Because of the undisturbed nature of this Middle Archaic component, it was recommended that the site be preserved (Katz 1977). The site is stil1 located within the environs of the John James Park, and it is hoped that it will remain undisturbed and not suffer the callous obliteration that occurred at 41 BX 194.

Another camp site, 41 BX 389, was found during the 1977 Fort Sam Houston survey just south of the MARS radio station within the floodplain of Salado creek. This site is $60 \times 40 \mathrm{~m}$ in size and consists of a wide surface scatter of cores, flakes, and burned rocks (Gerstle, Kelly, and Assad 1978:310-313). No artifacts indicative of specific chronological periods were recovered.

Another surface scatter of artifacts was found at 41 BX 422 , also within the limits of Fort Sam Houston. The site area was approximately $40 \times 60 \mathrm{~m}$. It consisted of a thin scatter of flakes, two core fragments, and a unifacial ovoid scraper. Gerstle, Kelly, and Assad (1978:313) concluded that it probably functioned as a temporary campsite or plant collecting locality. As in the case of $41 \mathrm{BX} 389$, no chronological artifact indicators were found. 
Farther away from the study area, approximately $0.8 \mathrm{~km}$ north of $41 \mathrm{BX} 305$, at the confluence of Salado and Walzem Creeks is 47 BX 294. This National Register site complex contains prehistoric and historic materials. This area is the location of the Battle of Salado Creek and the related Dawson Massacre, both of which occurred on September 18, 1842, during the second Mexican invasion of Texas (see below).

In summary, previous research in the Fort Sam Houston area and along the Lower Salado drainage demonstrates that the region was inhabited by aboriginal occupants from Paleo-Indian times throughout all subsequent periods (Gerstle, Kel1y, and Assad 1978; Katz 1977; Hester 1980). Most of these sites are located less than one kilometer from water sources. Thus, the study area, with its tributary stream and proximity to the Salado Creek, has a high potential for containing buried prehistoric sites.

\section{ENVIRONMENTAL SETTING}

\section{Physiography}

Fort Sam Houston is in the gently rolling hills of the Blackland Prairie physiographic area, which is a transitional zone between the higher relief Balcones Escarpment and the Gulf Coastal Plain Province (Taylor, Hailey, and Richmond 1966; Carr 1967; Freese and Nichols, Inc. 1977). The Salado Creek and its tributaries comprise the major drainage system that dissects the rolling hills of the study area. Much of this region is covered with gravelly terrace deposits that have been exposed in some areas by stream erosion (Freese and Nichols, Inc. 1977:15).

\section{Geology}

The earliest geologic deposits in the study area are loosely consolidated sediments of the Cretaceous age (ca. 75 million years $01 d$ ). The bedrock in the Fort Sam Houston area is defined as the Navarro Group and Marlbrook Marl and is overlain with Quaternary alluvial deposits. It is largely composed of clay, sandstone, marl, and siltstone and contains concretions of limonite, siderite, and siliceous limestone. Quartz, flint, and chert nodules are found as inclusions in the 1 imestone beds and in outcrops of siliceous gravels that have eroded from the parent limestone material along some slopes. The alluvium along Salado Creek and its tributaries consists largely of gravel, sand, and silt up to 45 feet thick (Arrow 1959). These terraces formed during the Pleistocene with recent alluvium forming the deposits in the present Salado Creek floodplain (Freese and Nichols, Inc. 1977:17). The soils in the study area consist of the Venus-Frio-Trinity series. The low-lying areas close to Salado Creek are typically Trinity and Frio soils. The soils on the upland terraces are of the Venus clay loam series (Taylor, Hailey, and Richmond 1966).

Elevations range from approximately 660 to 680 feet above mean sea level in the project area. 
Geomorphology

The Pleistocene alluvium that occurs along Salado Creek and its tributaries are made up of grave1, sand, and silt. In some places it is up to 45 feet thick and is a significant geomorphological feature. This geological feature is probably related to paleoclimatic phenomena. Gunn (1981:65) has suggested that these stream terraces were scoured from the drainage systems by extremely highenergy, single-event flooding episodes. Glen Evans, a geomorphologist, believes these gravels were deposited in the late Pleistocene (Black and McGraw 1982). This interpretation is supported by the evidence from several excavated archaeological sites within the Salado drainage (notably 41 BX 228, 41 BX 271, and 41 BX 300). Beneath the earliest occupations at these sites are extensive gravel deposits (Black and McGraw 1982). Recently it has been postulated that if these deep gravel deposits date to the late Pleistocene, then they may indicate a brief climatic interval of instability during the transition from the wet, cool conditions of the Pleistocene to the warmer conditions of the early Holocene approximately ten thousand years ago (Black and McGraw 1982).

\section{Local Environmental History}

Most paleoenvironmental data for Bexar County has accumulated from research outside of the study area--north of the Balcones Escarpment and in central and western Texas. In much of the world, palynological research has provided the best data regarding paleoenvironmental conditions. However, due to the subtropical climate of south Texas, fossil pollen is not well preserved, and other methods must be used to enhance paleoenvironmental reconstruction.

During the late Pleistocene glacial maximum known as the Wisconsin Glaciation, the ice extended as far south as the modern location of St. Louis, Missouri. Southern Texas at this time was primarily covered in piñon pine parkland (01dfield and Schoenwetter 1975). Somewhere around 8000 B.C. there may have been a period of climatic instability (as described above) during the transition from cool, wet Pleistocene conditions to the warmer Holocene period. Early in the Holocene the piñon pine parkland was gradually replaced by a grassland savanna (Bryant 1969; Bryant and Shafer 1977). Evidence derived from floral and faunal biosilica research by Robinson (1979) in Goliad County suggests that $\mathrm{climatic}$ fluctuations (altering moist and arid periods) characterized the Holocene. Robinson (1979) has postulated that a regional arid period prior to 1000 B.C. was preceded and followed by periods of much wetter conditions. A7though the evidence is preliminary, it seems that the mesic periods correspond to Holocene glacial advances and the xeric periods to glacial retreats. If these fluctuations did occur, game and other human food sources may also have undergone fluctuations in population size, and this would have affected human adaptations during the Archaic cultural historical period. At approximately 400 B.C. the paleoclimate in south Texas became similar to current conditions (Bryant and Shafer 1977; Robinson 1979).

Local Vegetation and Fauna

Like most of Bexar County and south Texas, the study area is included within the Tamaulipan Biotic Province (BTair 1950). Prior to historical settlement 
the region was characterized by the native Blackland Prairie plant communities mixed with Edwards Plateau and south Texas Coastal Plain species (Freese and Nichols, Inc. 1977). At present, the vegetation can be classified as urban. Approximately $75 \%$ of the study area is covered in a mixture of Texas grama, buffalo grass, and cane bluestem with mixed domestic grasses and various weeds. The southern 25\% of the study area (Fig. 1), closest to Salado Creek, has a variety of trees such as mesquite, hackberry, cedar, elm, and live oak. Mesquite trees predominate in this area.

A variety of fauna probably inhabit the area, although only birds were observed during the field work activities. Freese and Nichols, Inc., (1977:D83) have included the following mammals as probable inhabitants of the "wilder parts of the Post": armadillos, skunks, raccoons, opossums, and fox squirrels. Common herpetiles (reptiles and amphibians) include toads, tree frogs; and various species of garter and water snakes. Prior to historic and recent settlement of the Post, larger game species, such as white-tailed deer, were probably abundant.

\section{THE CHRONOLOGY OF PREHISTORIC OCCUPATION}

During the field work activities, no artifacts were found indicative of chronological periods, so this section consists only of a brief summary (for further details, see Hester 1980). The cultural history of Bexar County and south Texas can be divided into four major periods. The Paleo-Indian period (ca. 13,000 to 6000 B.C.) is represented by the occurrence of Folsom, Plainview, Angostura, Golondrina, and other large projectile points. The Archaic is the longest period (ca. 6000 B.C. to A.D. 1000); it is typified by a sequence of large projectile points of diverse shapes and styles that change through time. Additionally, numerous types of chipped stone tools (scrapers, gouges, and knives) as well as ground stone tools (manos, metates) indicate cultures adapted to a life of seminomadic hunting and gathering. This era is followed by the Late Prehistoric period (Ca. A.D. 1000-1600), which is characterized by the introduction of the bow and arrow as evidenced by small projectile points, locally called "bird points." Another cultural element of the Late Prehistoric period is the introduction of ceramics, notably bone-tempered, plainware pottery. The Historic period (post A.D. 1600) is demonstrated by habitation sites of historic Indian groups (Coahuilteco, Comanche, Apache) who possessed materials of European manufacture in addition to their own locally made artifacts. 0ther historic sites are, of course, the result of early Spanish and Anglo-European occupations.

\section{HISTORIC USE OF THE STUDY AREA}

The study area is near 41 BX 294, the site of the Battle of Salado Creek and the subsequent Dawson Massacre. Probably some of the antagonistic forces used this area to assemble or prepare for hostilities. On September 11, 1842, General Adrian Woll, a French soldier of fortune serving in the Mexican army, captured San Antonio with a force of about 1400 men, during what is known as the second Mexican invasion of Texas. Upon hearing of the fall of San Antonio, Mathew Caldwel1 raised a force of over 200 volunteers from the Gonzales and Seguin areas, who then moved to the Salado Creek area which, at that time, was about six miles east of San Antonio (Webb 1952). 
This page has been

redacted because it

contains restricted

information. 
On the morning of September 18, Caldwel1 dispatched John C. (Jack) Hays and a company of men to lure the Mexican force out of San Antonio. When the Mexican cavalry attacked, Hays retreated to the Texans' well-protected position on Salado Creek. Caldwell had deployed the rest of the Texans at this position, and they waited in ambush. The Mexican forces failed repeatedly to break the Texas 1 ine, and 60 Mexicans were killed and many others wounded (Webb 1952). In the main engagement, the Texans' only losses were one man killed and nine wounded. However, during the late fighting a company of Texans, under the command of Captain Nicholas Dawson, attempting to link up with the main body of troops, was cut off, surrounded, and all of the men were either killed or captured by the Mexicans. This incident became known as the Dawson Massacre (Webb 1952). Woll's forces retreated to Mexico on September 20, 1842.

The next recorded use of the study area was during the years 1886-1898 when the 31.68 acres of 1 and were part of a rifle range, used by the 18th Infantry Regiment and the 5th Cavalry. During this time the famed Rough Riders (also known officially as the 1st United States Cavalry Volunteers), under the command of Leonard Woods (who was assisted by Theodore Roosevelt), trained at Fort Sam Houston. They were stationed at the Post during the winter of 18971898 and were transferred to Florida in the spring of 1898 prior to their involvement in the Cuba campaign of the Spanish-American War. They may have used the rifle range located in the study area during their training time at Fort Sam Houston.

In the vicinity immediately northwest of the study area (where the U.S. Army Reserve Center is now located), one of the earliest (ca. 1908) aerodromes was constructed and was known as Dodd Field. This aerodrome functioned primarily as a training base, and the study area may have frequently been used as an emergency landing field (John Manguso, personal communication).

In 1916, the Cavalry Remount Station was established across Winans Road from the study area. The proximity of the Remount Station, with its 30,000 horse capacity, to Dodd Field caused a curtailment in training operations at the aerodrome. From 1917 to 1940 only observation airplanes were based at Dodd Field; the training operations used the facilities at Kelly Field during this time. In 1940, Dodd Field was closed.

The Remount Station operated until 1925. An aerial photograph taken in 1928 of the study area (on file at the Fort Sam Houston Museum), shows that most of the structures associated with the Remount Station have been disassembled. However, paths, roads, and outlines of the buildings show that it was a large facility. In fact, while it was in operation it was the largest such facility in the nation (John Manguso, personal communication). The study area located immediately to the south of the Remount Station undoubtedly was used as a training and staging area for the cavalry during this time.

In 1940, the first documented structures were erected in the northwest corner of the study area. These were of the typical two-story, army-style barracks variety. These structures were built for the induction center for processing draftees into the U.S. Army. The exact number of buildings that were constructed at this time is not known, but there must have been several, because these facilities had the capacity to process 1000 men through at a time (John Manguso, personal communication). 
In December 1941, the function of these structures was changed to a prison camp. During the early weeks of World War II, German and Italian nationals (then considered "enemy aliens") from south and east Texas, were detained there. In 1942, German prisoners-of-war captured by the British in Africa were sent to this camp. Beginning in 1943, German prisoners-of-war taken by U.S. forces were held there. A picture taken in the late 1940s (on file at the Fort Sam Houston Military Museum), shows 10 long, two-story barracks (in two rows of five structures each), 10 one-story barracks, and one very long, two-story building in the northwest corner of the study area.

Sometime after the early 1950s these buildings were torn down and no further record of their use is available. For approximately the last 20 years the south side of the study area has been used as a dump for backdirt from the Fort Sam Houston National Cemetery.

\section{THE PROJECT INVESTIGATIONS}

Methods

Following the literature review, archival research, and personal interviews, an intensive surface reconnaissance of the study area was conducted using standard archaeological survey procedures. Only one interior flake was found in the drainage channel during the reconnaissance. No other prehistoric artifacts on the sites were found. Scattered pieces of modern cultural debris were also observed in the drainage channel. Upon completion of all of these operations (archival research, 1 iterature review, personal interviews, and reconnaissance), the following characteristics of the study area were known:

1. The northwest quarter was severely disturbed by the construction and removal of the induction center, P.O.W. buildings, and their associated utilities (sewer, water, and gas lines).

2. The south side was covered in deep deposits of backdirt from the National Cemetery.

3. The east side had been disturbed to an undetermined extent by gravelborrowing about 50 years ago (this information came from an interview with a local informant who prefers anonymity).

4. The only portion of the study area not to receive some form of alteration was the area immediately adjacent to the drainage channel (particularly where it forks in the north side of the study area).

In planning the subsurface archaeological testing program, it was decided that in spite of all the modifications to the study area, all sectors should be tested if only to assess the nature and extent of these disturbances. Additionally, the project director thought that since previous archaeological research in the local vicinity had demonstrated prehistoric occupation sites close to water sources, the areas nearest the drainage in the study area should be extensively sampled. Also, it was recognized that since so much 1 and modification had been conducted in the study area, planning a detailed stratified representative sampling strategy would not be an efficient use of time, and 
that decisions regarding placement of backhoe trenches would necessarily have to be made in the field based on the information gained from the initial testing in each area. As is demonstrated in the following description of these backhoe tests, this was a valid decision. In the first six units excavated we learned that in the area west of BT2 (Backhoe Trench Number 2), BT3, BT5, and BT6 (Fig. 1), prior to dumping backdirt, the land surface was bladed down to subsurface gravel. The decision was made in the field to do no further testing west of these units. Similar decisions were made regarding further testing in the vicinity of the German P.O.W. camp area, to the south of Backhoe Trench No. 33, and in the northeast quadrant of the study area (Fig. 1). Generally in the other areas tested, an interval of 60 to $70 \mathrm{~m}$ (200 feet approximately) between the backhoe tests was used, unless cultural debris was encountered. Upon discovering the cultural material in the vicinity of $41 \mathrm{BX} 346$, the spacing interval was halved--to $30 \mathrm{~m}$ or less (Fig. 1). Test Pits 1 and 2 were excavated according to arbitrary levels. The thickness of the levels was determined by expected depth of disturbances seen in the adjacent backhoe tests. In Test Pit 1 for example, we expected disturbance to at least $20 \mathrm{~cm}$ below surface, but as we excavated we found that the whole upper $30 \mathrm{~cm}$ (the entire cultural layer) was badly mixed, so we excavated it as one arbitrary $30 \mathrm{~cm}$ level. The subsurface indications were less clear at Test Pit 2, although we knew the upper $20 \mathrm{~cm}$ was disturbed and accordingly, it was excavated as one arbitrary $20 \mathrm{~cm}$ level. Subsequent Test Pit 2 levels were arbitrarily $10 \mathrm{~cm}$ thick, but unfortunately all of these levels (to a depth of $60 \mathrm{~cm}$ below surface) were disturbed (see also pages 39-44 of this report). Analysis of the recovered materials was restricted to the function and technology represented by prehistoric lithic artifacts. Analysis was methodologically limited owing to the disturbed nature of the remains at $41 \mathrm{BX} 346$.

\section{Artifact Terminology}

The following artifact categories and terms are defined and derived from Crabtree (1972) and Gibson (1981).

Bifaces: These are tools that have had flake removals from both the dorsal and ventral surfaces and also along at least one edge of the implement. In this report bifaces are separated into thin (less than $5 \mathrm{~mm}$ ) or thick categories. In some cases, thin bifaces were probabily used as cutting tools or knives, and also may have been "preforms," which are bifaces that may have been intended for further modification into knives or projectile points.

Chunk: These are angular pieces of raw material removed during initial reduction of the core. They are often brittle and fragmentary and usually have one or more cortex faces, but lack an identifiable blub and/or platform.

Cores: Cores are pieces of siliceous stone or other raw materials that have at least one surface from which flakes have been removed.

Cortex: A stone's natural, weathered surface.

Flake: A piece of stone that has been removed from a core (or other artifact) through the introduction of force into the core. In this report, flakes are 
considered to be only the result of human flintworking activities. Diagnostic attributes of a flake are: a striking platform, ripples, fissures, and a bulb of percussion (Crabtree 1972).

Flakes with Edge Modification: These are flakes that show modification on one or more edges. However, whether the edge modification resulted from cultural or natural processes is indeterminate on these specimens.

Interior Flake: A flake lacking cortex, usually the most common flake form found at a site. Interior flakes are flintworking debitage produced from a core, another flake, or a tool which has had all the cortex detached from previous flake removals.

Primary Cortex Flake: A flake characterized by a cortex dorsal surface.

Projectile Point: Usually a bifacial tool used on the distal end of a projectile such as an arrow, atlatl dart, or spear, commonly known as an "arrowhead."

Scrapers: These formatized tools show either unifacial or bifacial modification. They may also have steep edge angles. Wear patterns are often common along edges in the form of edge damage, striations, and/or polish.

Secondary Cortex Flake: A flake characterized by some cortex remaining on the dorsal surface. These flakes are indicative of flintworking activities.

Unifaces: Unifaces are tools that have been modified on only one surface and one edge. Edge modification in this case was the result of intentional retouch and use. The uniface category applies to any nonformalized unifacially worked tool (does not apply to scrapers).

Utilized Flakes: These are tools that have been modified on one or more edges or surfaces through use and not intentional retouch.

Description of Backhoe Test Units

Backhoe Trench 1

Length: $11.8 \cdot \mathrm{m}$

Maximum Depth: $2.8 \mathrm{~m}$

Width: $0.65 \mathrm{~m}$

Orientation: East/West

Activities of Recorders: Dimensions were taken; profiles cleaned and examined, and the profile drawn.

Description of Stratigraphy: Zone 4 was 20 to $30 \mathrm{~cm}$ of mixed fill or overburden. Zone 3 consisted of a dark brownish gray (Munsel1 Color 2.5 YR 4/0) clayey alluvium (ca. $40 \mathrm{~cm}$ thick). Zone 2 contained a transitional layer of dark tannish yellow 
clay (Munsel1 Color 10 YR 7/6) gradually becoming lighter in color (ca. $30 \mathrm{~cm}$ thick). Zone 1 contained bright yellow clay (Munsel1 Color 10 YR 7/8) extending to an unknown depth and two lenses of rounded, pea-sized gravel.

Materials Recovered: Two chert cobbles were collected for material sample.

\section{Backhoe Trench 2}

Length: $7.40 \mathrm{~m}$

Maximum Depth: $2.60 \mathrm{~m}$

Width: $0.65 \mathrm{~m}$

Orientation: East/West

Activities of Recorders: Dimensions were taken, and profiles checked for cultural debris, but no profiles were drawn.

Description of Stratigraphy: No undisturbed strata. Soil is predominantly fill as evidenced by a broken marble tombstone fragment from the National Cemetery embedded in the east profile approximately $1.3 \mathrm{~m}$ below surface. Below this is alluvial gravel; thus indicating that the topsoil has previously been scraped away.

Materials Recovered: None

Backhoe Trench 3

Length: $7 \mathrm{~m}$

Maximum Depth: $2.25 \mathrm{~m}$

Width: $0.65 \mathrm{~m}$

Orientation: North/South

Activities of Recorders: Dimensions were recorded, and profiles examined and cleaned.

Description of Stratigraphy: The upper $1.9 \mathrm{~m}$ consists of disturbed overburden; a golf ball was observed in the profile at $1.8 \mathrm{~m}$ below surface. Below $1.9 \mathrm{~m}$ a small, thin layer of alluvium (ca. $10 \mathrm{~cm}$ thick) containing root intrusions was observed. This may have been the original ground surface. Below this was a silty clay layer that extended to the bottom of the trench. This clay changes in color from reddish brown (Munsell Color 5 YR 4/4) to light yellow. (Munse11 Color 10 YR 8/6) at the bottom with no clear boundaries. In the bottom sma17to medium-sized gravels are included in the light yellow zone.

Materials Recovered: None 
Backhoe Trench 4

Length: $4.9 \mathrm{~m}$

Maximum Depth: $2.9 \mathrm{~m}$

Width: $0.65 \mathrm{~m}$

Orientation: East/West

Activities of Recorders: Dimensions were taken, and the walls were scraped and examined for cultural materials. None were noted.

Description of Stratigraphy: There is a very deep deposit of mixed fill and backdirt from the cemetery (overburden). The strata can be summarized as follows: Leve1 1 is approximately $2.5 \mathrm{~cm}$ thick (variable) from surface. It is all overburden material consisting of mixed clay, silt, and caliche, varying in color from yellow (Munsell Color 10 YR 7/6) to tan to grayish brown (Munsel1 Color 10 YR 5/2). Level 2 is a brown (Munsell Color 10 YR 5/3) silty zone with root intrusions; approximately $5-10 \mathrm{~cm}$ thick and intermittent--does not extend across all profiles. Level 3 is a transitional silty clay, very homogeneous approximately $1.3 \mathrm{~m}$ thick. Level 4 is a yellowish (Munsell color 10 YR 7/8) clay with small gravel and it extends to an unknown depth.

Materials Recovered: None

\section{Backhoe Trench 5}

Length: $7.4 \mathrm{~m}$

Maximum Depth: $2.65 \mathrm{~m}$

Width: $0.65 \mathrm{~m}$

Orientation: North/South.

Activities of Recorders: Dimensions were taken; profiles scraped and examined, but profiles were not drawn.

Description of Stratigraphy: Level 1 is a mixed overburden Tayer which extends to approximately $1 \mathrm{~m}$ below surface. Level 2 is a dense, homogeneous brown (Munse11 Color 10 YR 5/3) clay layer without roots. It extends to approximately $2.5 \mathrm{~m}$ below surface where a yellow (Munsell Color 10 YR 7/8) clay layer (Level 3) is encountered.

Materials Recovered: None 
Backhoe Trench 6

Length: $6.30 \mathrm{~m}$

Maximum Depth: $1.70 \mathrm{~m}$

Width: $0.65 \mathrm{~m}$

Orientation: East/West

Activities of Recorders: Dimensions were taken; profiles scraped and examined, but no profiles were drawn.

Description of Stratigraphy: Leve1 1, a mixed overburden layer, extends to a depth of $0.40 \mathrm{~m}$ below surface. Level 2 is a homogeneous brown (Munsell color 10 YR 5/3) clay with a few small pebbles and is approximately $50 \mathrm{~cm}$ thick. Level 3 is very similar to Level 2, but is slightly lighter and approximately $50 \mathrm{~cm}$ thick. Level 4 is a light yellow (Munsell Color 10 YR 7/6) clay with rounded gravel inclusions and approximately $40 \mathrm{~cm}$ thick.

Comments: Judging from the thin layer of mixed overburden, this area may have been at a higher elevation or not bladed down before backdirt was dumped here.

Materials Recovered: None

\section{Backhoe Trench 7}

Length: $6.2 \mathrm{~m}$

Maximum Depth: $2.1 \mathrm{~m}$

Width: $0.65 \mathrm{~m}$

Orientation: East/West

Activities of Recorders: The walls were scraped and examined; no profiles were drawn.

Description of Stratigraphy: Leve1 $1,85 \mathrm{~cm}$ of mixed overburden, contains buried tree branches and various mixed soils. Level 2 is a medium brown (Munsell Color 7.5 YR 4/2) silty clay/clayey loam, which contains random small, white calcite concretions and is approximately $70 \mathrm{~cm}$ thick. Level 3 is a reddish brown (Munsell Color 5 YR 4/4) silty clay, also with occasional small, whitish (Munsel1 Color 7.5 YR 8/2) calcite concretions. This level is approximately $30 \mathrm{~cm}$ thick. Level 4 is a yellowish (Munsell Color 7.5 YR 6/8) clay, very compact, $25 \mathrm{~cm}$ thick, with occasional whitish (Munsell Color 7.5 YR 8/2) concretions and no gravel.

Materials Recovered: One horseshoe was recovered from the backdirt. No provenience was recorded. 
Backhoe Trench 8

Length: $6.80 \mathrm{~m}$

Maximum Depth: $2.40 \mathrm{~m}$

Width: $0.65 \mathrm{~m}$

Orientation: North/South

Activities of Recorders: Dimensions were taken, and profiles cleaned and examined. No profiles were drawn.

Description of Stratigraphy: Level 1 is a mixed overburden layer, approximately 60 to $70 \mathrm{~cm}$ thick at the north end and $1.20 \mathrm{~m}$ thick at the south end. Level 2 is a dark brown (Munsel1 Color 7.5 YR 3/2) clay one meter thick at the north end and $0.80 \mathrm{~m}$ thick at the south end. Level 3 is a light brown (Munsell Color 10 YR 6/4) clay layer with small limestone pebble inclusions ca. $30 \mathrm{~cm}$ thick. Level 4 is a pale brown (Munsell Color 10 YR 6/3) clay visible in the bottom $5 \mathrm{~cm}$ of the trench.

Materials Recovered: None

Backhoe Trench 9

Length: $8 \mathrm{~m}$

Maximum Depth: $2.8 \mathrm{~m}$

Width: $0.65 \mathrm{~m}$

Orientation: North/South

Activities of Recorders: The walls were cleaned and examined; no profiles were drawn.

Description of Stratigraphy: Only two levels were observed in this trench. Level 1, the upper two meters, is composed of badly mixed overburden. Level 2 is a dark grayish brown (Munsell Color 10 YR 4/2) clay.

Materials Recovered: None

Backhoe Trench 10

Length: $6.70 \mathrm{~m}$

Maximum Depth: $3.15 \mathrm{~m}$

Width: $0.65 \mathrm{~m}$

Orientation: East/West 
14Activities of Recorders: Dimensions were taken, and profiles were examined. One chert cobble was collected for material sample. No profiles were drawn.

Description of Stratigraphy: As in the case of BT9, only two levels were observed in this trench. The highly mixed overburden of Level 1 extends to a depth of $1.4 \mathrm{~m}$ below the surface. Level 2 is a dark brown (Munsell Color 10 YR 3/3) homogeneous clay ca. $1.75 \mathrm{~m}$ thick and extends to an unknown depth below the bottom of the trench.

Materials Recovered: One chert cobble was collected for material sample.

Backhoe Trench 11

Length: $6.5^{\circ} \mathrm{m}$

Maximum Depth: $2.6 \mathrm{~m}$

Width: $0.65 \mathrm{~m}$

Orientation: Northwest/Southeast

Activities of Recorders: The walls were scraped and examined, and dimensions taken. No profiles were drawn.

Description of Stratigraphy: Level 1 is the overburden layer, $1.6 \mathrm{~m}$ thick, and a morass of discarded phone cables and wires $0.80 \mathrm{~m}$ below surface. Level 2 is $90 \mathrm{~cm}$ thick and consists of a medium brown (Munsel1 Color 10 YR 3/4) silty loam. Included in this level are sma71-rounded gravels.

Materials Recovered: None

Backhoe Trench 12

Length: $6.10 \mathrm{~m}$

Maximum Depth: $2.0 \mathrm{~m}$

Width: $0.65 \mathrm{~m}$

Orientation: Northeast/Southwest

Activities of Recorders: Dimensions were taken; profile examined, cleaned, and drawn; artifacts were provenienced and collected.

Description of Stratigraphy: This unit has the most complex strata encountered so far. Leve1 $1,0.60-0.70 \mathrm{~m}$ in depth from surface, is a 1ight brown gray (Munsel1 Color 10 YR 6/2) friable silt mixed with pea- to marbie-sized, rounded gravels (alluvium). Level 2, $0.50 \mathrm{~m}$ thick, is a dark brown gray (Munsell color 10 YR 4/2) clayey silt with pea-sized gravels intermixed (contains charcoal flakes). Level 3 is a caliche (Munsell color 10 YR 8/4) gravel lens, 2-13 cm thick. Level 4, $0.45 \mathrm{~m}$ thick, is a brown gray (Munse11 Color 10 YR 5/2) clayey 
silt, similar to Level 2, but lacks gravel. Level $5,0.20 \mathrm{~m}$ thick, is a reddish tan (Munsell Color 5 YR 5/4) clay containing some calcareous concretions.

Materials Recovered: The provenienced materials included one horseshoe from $0.30 \mathrm{~m}$ below surface, one exhausted core $0.25 \mathrm{~m}$ below surface, and one blade fragment $0.40 \mathrm{~m}$ below surface. The nonprovenienced materials were one square nail and numerous historic ceramic and glass sherds (ca. late 19th/early 20th century).

Backhoe Trench 13

Length: $9.2 \mathrm{~m}$

Maximum Depth: $1.65 \mathrm{~m}$

Width: $0.65 \mathrm{~m}$

Orientation: Northeast/Southwest

Activities of Recorders: Dimensions were taken; profiles examined, and carbonized materials provenienced and collected.

Description of Stratigraphy: Level 1 extends from the surface to approximately $35 \mathrm{~cm}$ below surface and is a friable brownish gray (Munsell Color 10 YR 5/2) silty loam. Level 2 is a transitional soil; a yellowish tan (Munsell Color 10 YR 7/6) compacted clayey loam with occasional sma11 gravel inclusions, approximately $25 \mathrm{~cm}$ thick. Level 3 is a one meter thick layer and consists of a light yellowish orange (Munse11 Color 7.5 YR 6/6) clay containing a heavy admixture of calcareous concretions and occasional large rounded cobbles and gravels.

Materials Recovered: Carbonized material was collected from Level 3.

Backhoe Trench 14

Length: $8.8 \mathrm{~m}$

Maximum Depth: $1.35 \mathrm{~m}$

Width: $0.65 \mathrm{~m}$

Orientation: North/South

Activities of Recorders: Dimensions were taken; profiles cleaned and drawn, and cultural materials provenienced and collected.

Description of Stratigraphy: Level 1 is a brownish gray (Munsel1 Color 10 YR 5/2) friable silty soil approximately $20 \mathrm{~cm}$ thick containing smal1 to large cobbles and historic and prehistoric materials. Level 2 is $20 \mathrm{~cm}$ of brownish gray (Munse11 Color 10 YR 4/2) silt, slightly more compact than 
Level 1 with no cobbles or gravel. Level 3 is $65 \mathrm{~cm}$ thick. It is a light brown (Munsel1 Color 10 YR 6/4) compacted clayey soil containing a few scattered limestone pebbles and occasional chert cobbles. Level 4 is a gravel layer in the bottom $20 \mathrm{~cm}$ of the trench. The gravel is small and rounded, undoubtedly alluvial in origin and extends to an unknown depth below the unit.

Materials Recovered: Two leather (?) fragments, one horseshoe, two chert cores, and one possible worked piece of dolomite were recovered (Fig. 2).

Backhoe Trench 15

Length: $12.50 \mathrm{~m}$

Maximum Depth: $1.10 \mathrm{~m}$

Width: $0.65 \mathrm{~m}$

Orientation: East/West

Activities of Recorders: Dimensions were taken and profiles examined.

Description of Stratigraphy: Level 7 is a loose brown gray (Munsel1 Color 10 YR 5/2) silty loam and extends from the surface to a depth of $35 \mathrm{~cm}$. Level 2 is a brown (Munse11 Color 10 YR 4/3) compacted clayey silt, approximately $50 \mathrm{~cm}$ thick. Leve 3 is $25 . \mathrm{cm}$ thick and a light tan (Munsell Color 10 YR 7/4) calcareous river gravel deposit.

Materials Recovered: None

Backhoe Trench 16

Length: $8.9 \mathrm{~m}$

Maximum Depth: $0.80 \mathrm{~m}$

Width: $0.65 \mathrm{~m}$

Orientation: North/South

Activities of Recorders: Dimensions were recorded; walls cleaned and examined, but no profiles drawn.

Description of Stratigraphy: Level 1 is a dark grayish brown (Munsell Color 10 YR 4/2) clayey friable loam, containing occasional small gravels, approximately 10-15 cm thick. Level 2 is a reddish brown (Munse1] Color 5 YR 4/4) clayey loam more compact than Level 1. Thickness varies from 5 to $10 \mathrm{~cm}$ and contains small- to medium-sized gravel. Level 3 is a yellowish tan (Munsell Color 7.5 YR 6/6) soil with a heavy gravel component. Gravel constitutes most of this level and ranges from small (pea size) to large (fist size).

Materials Recovered: One curved metal fragment was collected. 


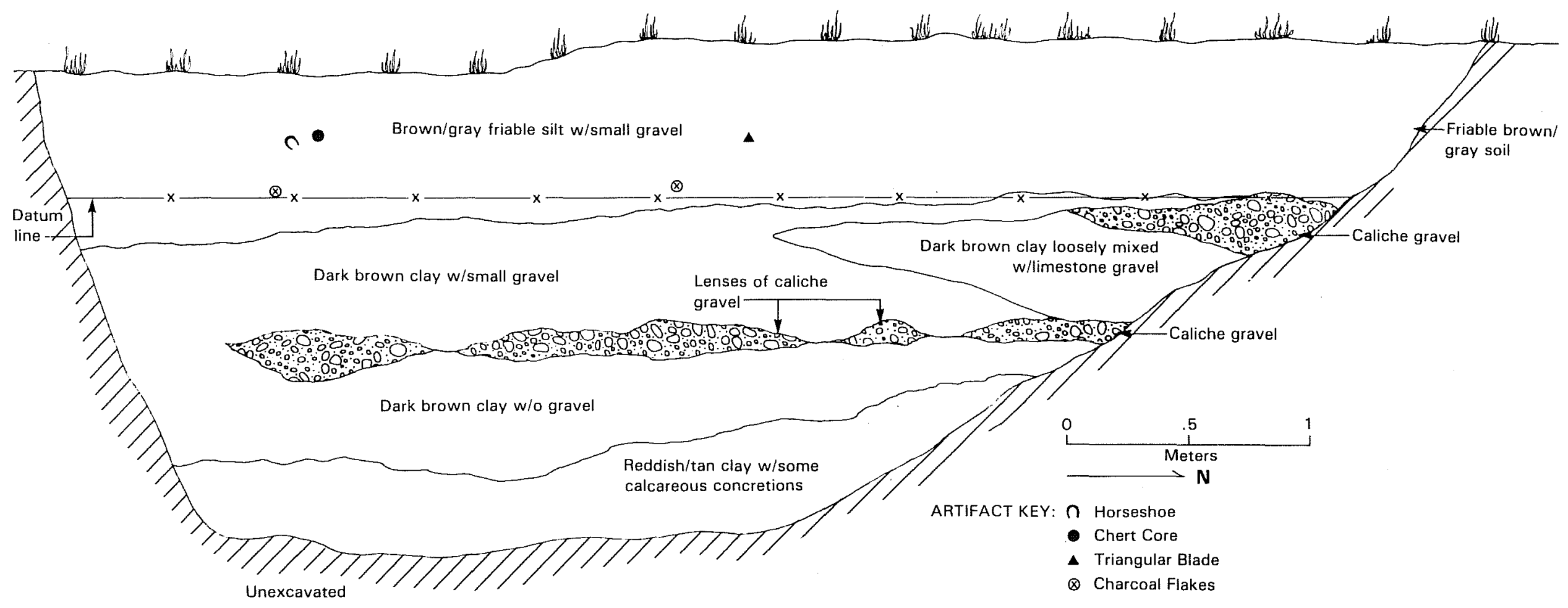

Figure 2. Profile of Backhoe Test Unit 14. 
Backhoe Trench 17

Length: $6.2 \mathrm{~m}$

Maximum Depth: $0.65 \mathrm{~m}$

Width: $90 \mathrm{~m}$

Orientation: East/West

Activities of Recorders: The walls were scraped and examined for cultural materials. Materials were collected, and dimensions were recorded. No profiles were drawn.

Description of Stratigraphy: Leve1. 1 is approximately 10 to $20 \mathrm{~cm}$ of friable, gravelly soil, light gray (Munsell Color 7.5 YR 7/7) in color. Included in this level are several lenses (both walls) of an asphaltlike material (sample taken). The bolt and glass fragments came from this level. Level 2 is a reddish brown (Munse11 Color 5 YR 4/4) silty loam approximately 20-30 cm thick. Level 3 is a light reddish brown (Munse11 Color 5 YR 6/4) silty loam approximately $15-20 \mathrm{~cm}$ thick. Level 4 is like Level 3, but has a higher gravel content.

Materials Recovered: Materials collected were one flake, one bottle base (early 20th century), one bolt fragment, one glass fragment, and one sample of an asphaltlike material.

Backhoe Trench 18

Length: $3.8 \mathrm{~m}$

Maximum Depth: $1.1 \mathrm{~m}$

Width: $0.65 \mathrm{~m}$.

Orientation: East/West

Activities of Recorders: Dimensions were taken, and walls were scraped and examined.

Description of Stratigraphy: Level 1 is a friable dark brown (Munsell color 7.5 YR 3/4) loose silty soil approximately $20 \mathrm{~cm}$ thick and very dry. Level 2 is a reddish brown (Munsell Color 5 YR 4/4) clayey silt, approximately $30-40 \mathrm{~cm}$ thick. Level 3 is a yellowish red (Munsell color 5 YR 6/8) tightly compacted clayey soil, with calcareous concretions and some small gravel.

Comments: Level 1 seems to be a recently formed topsoil level predominantly colluvial in origin.

Materials Recovered: One piece of badly eroded iron, one charcoal sample, and one piece of a document or printed material from Level 7 was recovered. 
Backhoe Trench 19

Length: $12.2 \mathrm{~m}$

Maximum Depth: $1.3 \mathrm{~m}$

Width: $0.65 \mathrm{~m}$

Orientation: North/South

Activities of Recorders: The walls were scraped and examined for cultural materials. Dimensions were recorded, but profiles not drawn.

Description of Stratigraphy: Level 1 is a dark brown (Munsel1 Color 7.5 YR 4/4) silty loam 30-40 cm deep, loosely compacted. Charcoal was scattered throughout this leve1. Level 2 is a reddish brown (Munsell Color 5 YR 4/4) tightly compacted clayey silt (approximately $50-70 \mathrm{~cm}$ below surface). Level 3 is a light reddish tan (Munse11 Color 5 YR 5/8) stratum with tightly compacted gravel ranging from pea- to fist-sized. A smal1 burned area $30 \mathrm{~cm}$ wide and $20 \mathrm{~cm}$ deep was observed in the south wall (possibly a burned tree stump?).

Materials Recovered: None

Backhoe Trench 20

Length: $4.25 \mathrm{~m}$

Maximum Depth: $0.95 \mathrm{~m}$

Width: $0.65 \mathrm{~m}$

Orientation: North/South

Activities of Recorders: Dimensions were taken. The profile was scraped and examined. Some charcoal was found and collected, but no profile drawn.

Description of Stratigraphy: Leve1 1 is approximately $0.30 \mathrm{~m}$ of a loose friable brownish gray (Munse11 Color 10 YR 4/2) strata without gravel, very loosely consolidated. Level 2 is $0.55 \mathrm{~m}$ of light brown (Munsel1 Color 10 YR 6/3) compacted silty clay containing small limestone gravels scattered throughout. Level 3 is a light tan (Munsel1 Color 19 YR 7/4) clay and gravel matrix.

Materials Recovered: A charcoal sample was collected from Level 1.

Backhoe Trench 21

Length: $4.1 \mathrm{~m}$

Maximum Depth: $1 \mathrm{~m}$

Width: $0.65 \mathrm{~m}$ 
Orientation: North/South

Activities of Recorders: The walls were scraped and examined. Dimensions were taken, but no profiles drawn.

Description of Stratigraphy: Level 1 is a friable brownish gray (Munse11 Color 10 YR 4/2) loosely consolidated silty loam with heavy root disturbances (trees nearby). It is approximately $20-30 \mathrm{~cm}$ thick. Level 2 is a light reddish tan (Munsel1 Color 7.2 YR 6/8) tightly compacted silty clay approximately $40 \mathrm{~cm}$ thick. Level 3 is a light reddish (Munsell Color 5 YR 5/6) clay containing some gravel and calcareous concretions, approximately $10-15 \mathrm{~cm}$ thick.

Materials Recovered: None

Backhoe Trench 22

Length: $4.1 \mathrm{~m}$

Maximum Depth: $0.95 \mathrm{~m}$

Width: $0.65 \mathrm{~m}$

Orientation: Northwest/Southeast

Activities of Recorders: Dimensions were taken; then the walls were scraped and examined.

Description of Stratigraphy: Leve 1 is 20 to $25 \mathrm{~cm}$ thick and consists of a friable grayish brown (Munsell Color 10 YR 5/2) silty soil, loosely consolidated with heavy root disturbances. Leve 2 is $30 \mathrm{~cm}$ thick and is a compacted light gray (Munse11 Color 10 YR 6/2) clay containing occasional small nodules. Level 3 is $25 \mathrm{~cm}$ thick and is a well-compacted 1ight tan (Munsell Color 10 YR 7/6) clay.

Materials Recovered: None-

Backhoe Trench 23

Length: $6 \mathrm{~m}$

Maximum Depth: $1.95 \mathrm{~m}$

Width: $0.65 \mathrm{~m}$

Orientation: Northeast/Southwest

Activities of Recorders: The walls were cleaned and profiled. Dimensions were taken. Profiles were not drawn. 
Description of Stratigraphy: Level 1 is $15 \mathrm{~cm}$ of a grayish brown (Munse11 Color 10 YR 5/2) loam with pebbles and roots. Level 2 is dark brownish black clay (Munse11 Color 10 YR 3/2) clay with scattered limestone pebbles, approximately $20 \mathrm{~cm}$ thick except at the north end of the trench where this layer disappears. Level 3 is a light brown (Munsel1 Color 10 YR 5/4) clayey silt containing fragments of 1 imestone at the north end of the trench. This level underlies Level 1. Level 4 is $60 \mathrm{~cm}$ of dark brown (Munsell Color 10 YR 3/3) silty clay with some limestone pebbles scattered throughout. Level 5 is a reddish brown (Munsell Color 5 YR 4/4) silty clay approximately $40 \mathrm{~cm}$ thick. Level 6 is $20 \mathrm{~cm}$ of tannish (Munsel1 Color 7.5 YR 6/4) clay with a high amount of limestone gravels.

Materials Recovered: None

\section{Backhoe Trench. 24}

Length: $6.1 \mathrm{~m}$

Maximum Depth: $1.90 \mathrm{~m}$

Width: $0.65 \mathrm{~m}$

Orientation: North/South

Activities of Recorders: Dimensions were taken; walls scraped and examined, and artifacts collected.

Description of Stratigraphy: Level 1 is $30 \mathrm{~cm}$ thick and is a dark grayish brown (Munsel1 Color 10 YR 4/2) friable loamy soil with occasional gravels present. The gravel lens in Level 1 is at the southern end of the trench. Occasional charcoal flakes were present in this level. Level 2 is a tightly compacted brownish gray (Munsell Color 10 YR $5 / 2$ ) clay approximately $1.2 \mathrm{~m}$ thick. Level 3 is $30 \mathrm{~cm}$ thick and is a compacted clay with occasional calcareous concretions. It is yellowish brown to yellow (Munsell Color 10 YR 6/8) in color.

Materials Recovered: Two interior flakes and one exhausted core were collected from Leve1 1.

\section{Backhoe Trench 25}

Length: $6.25 \mathrm{~m}$

Maximum Depth: $1.85 \mathrm{~m}$

Width: $0.65 \mathrm{~m}$

Orientation: East/West

Activities of Recorders: The walls were cleaned and examined; dimensions taken, but no profiles drawn. Artifacts were collected from the backdirt. 
Description of Stratigraphy: Leve 1 is $20 \mathrm{~cm}$ thick and is on dark grayish brown (Munse11 Color 10 YR 4/2) silt containing numerous roots and some smal1 gravel. Two burned stones were observed in this level. Level 2 is $20-25 \mathrm{~cm}$ thick and is a solid gravel layer, which fades out at the east end. Level 3 is a $1.15 \mathrm{~m}$ thick dark brown (Munsel1 Color 10 YR 3/3) silty clay with some limestone pebbles. Level 4 is $20 \mathrm{~cm}$ of orange (Munsell Color 5 YR 5/8) clay, containing numerous angular gravels.

Materials recovered: One exhausted core and one interior flake were collected.

Backhoe Trench 26

Length: $4.2 \mathrm{~m}$

Maximum Depth: $1.4 \mathrm{~m}$

Width: $0.65 \mathrm{~m}$

Orientation: Northeast/Southwest

Activities of Recorders: Dimensions were taken, and walls cleaned and examined. No profiles were drawn.

Description of Stratigraphy: Leve1 1, a grayish brown (Munsel1 Color 10 YR 5/2) friable silty loam approximately $25 \mathrm{~cm}$ thick, contains rounded, small gravels (pea size). A Rabdotus shell was noted at the base of this level. Leve1 1 . slopes to the south. Level 2 is approximately $60 \mathrm{~cm}$ of dark brown (Munsel1 Color 10 YR 3/3) silty clay with occasional smal1 limestone pebbles. Level 3 is similar to Leve1 2, except it is a much lighter brown (Munsell Color 10 YR 5/6) grading to a tan color. Level 4 is an orange-colored (Munsell color 5 YR 5/8) clay, approximately $10 \mathrm{~cm}$ thick in bottom of trench.

Materials Recovered: One core fragment was recovered.

Backhoe Trench 27

Length: $5.6 \mathrm{~m}$

Maximum Depth: $1.75 \mathrm{~m}$

Width: $0.65 \mathrm{~m}$

Orientation: Northeast/Southwest

Activities of Recorders: Dimensions were taken; profiles cleaned and examined, but no profiles drawn.

Description of Stratigraphy: Level 7 is 65 to $70 \mathrm{~cm}$ of badly disturbed, mixed overburden. Level 2 is $40 \mathrm{~cm}$ of dark brown (Munse11 Color 10 YR 3/3) clayey silt. Level 3 is a lighter grayish brown (Munsell Color 10 YR 5/2) clayey 
silt approximately $65 \mathrm{~cm}$ thick. Level 4 is an orange (Munsell Color 5 YR 5/8) clay, which is visible in the bottom $5 \mathrm{~cm}$ of this trench.

Materials Recovered: None

Backhoe Trench 28

Length: $3.8 \mathrm{~m}$

Maximum Depth: $2.15 \mathrm{~m}$

Width: $0.65 \mathrm{~m}$

Orientation: Nörth/South

Activities of Recorders: The dimensions were taken, and profiles cleaned and examined. Profiles were not drawn.

Description of Stratigraphy: Leve 1 is 50 to $60 \mathrm{~cm}$ of disturbed overburden. Leve1 2 is approximately one meter of dark grayish brown (Munsell Color

10 YR 4/2) silty clay. Level 3 is 30 to $40 \mathrm{~cm}$ of light brown (Munsell Color 10 YR 6/4) silty clay. Level 4 is $15 \mathrm{~cm}$ of orange (Munsell Color 5 YR 5/8) clay in the bottom of the trench.

Materials Recovered: None

Backhoe Trench 29

Length: $4.0 \mathrm{~m}$

Maximum Depth: $1.4 \mathrm{~m}$

Width: $0.65 \mathrm{~m}$

Orientation: North/South

Activities of Recorders: The dimensions were taken. Profiles were not drawn, but they were cleaned and examined.

Description of Stratigraphy: Leve 1 is $20 \mathrm{~cm}$ of dark grayish brown (Munse 11 Color 10 YR 4/2) silty loam and overburden mixed. Level 2 is a dark brown (Munse11 Color 10 YR 3/3) clayey silt without gravels, approximately $65 \mathrm{~cm}$ thick. Leve1 3 consists of loosely compacted rounded and angular orange (Munse11 Color 5 YR 5/8) gravels.

Materials Recovered: None 
Backhoe Trench 30

Length: $4.0 \mathrm{~m}$

Maximum Depth: $1.3 \mathrm{~m}$

Width: $0.65 \mathrm{~m}$

Orientation: North/South

Activities of Recorders: Dimensions were taken. Profiles were cleaned and examined. No profiles were drawn.

Description of Stratigraphy: Level 1 is overburden and disturbed topsoil mixed, approximately $20 \mathrm{~cm}$ thick. Level 2 is a dark brownish (Munsel1 Color 10 YR 3/3) clay approximately one meter thick. Level 3 is a layer of orange (Munsel1 Color 5 YR 5/8) gravel containing angular and rounded pebbles, only visible in the bottom $10 \mathrm{~cm}$ of the east wall.

Materials Recovered: None

Backhoe Trench 31

Length: $4 \mathrm{~m}$

Maximum Depth: $1.6 \mathrm{~m}$

Width: $0.65 \mathrm{~m}$

Orientation: North/South

Activities of Recorders: Dimensions were taken. Profiles were cleaned and examined (not drawn).

Description of Stratigraphy: Level 1 is the disturbed overburden layer, approximately $20 \mathrm{~cm}$ thick. Leve 12 is $6 \mathrm{~cm}$ of caliche and gravel that appears to be redeposited. Level 3 is a dark brownish gray (Munsel1 Color 10 YR 4/2) clayey silt, approximately $95 \mathrm{~cm}$ thick. Level 4 is a light brown (Munse11 Color 10 YR 6/4) silty clay, approximately $30 \mathrm{~cm}$ thick. Level 5 is orange (Munse 11 Color 5 YR 5/8) gravel in a clay matrix, approximatly $10 \mathrm{~cm}$ thick.

Materials Recovered: None

Backhoe Trench 32

Length: $3.8 \mathrm{~m}$

Maximum Depth: $1.9 \mathrm{~m}$

Width: $0.65 \mathrm{~m}$ 
Orientation: North/South

Activities of Recorders: Profiles were cleaned and examined, and dimensions taken, but profiles were not drawn.

Description of Stratigraphy: Leve 1 is $40 \mathrm{~cm}$ of redeposited overburden. Level 2 is a dark brownish gray (Munsell Color 10 YR 4/2) clayey silt, approximately $95 \mathrm{~cm}$ thick. Level 3 is a grayish light brown (Munsel1 Color 10 YR 6/2) clayey silt, approximately $40 \mathrm{~cm}$ thick. Level 4 is $20 \mathrm{~cm}$ of orange (Munsell Color 5 YR 5/8) gravels in a clay matrix.

Materials Recovered: None

\section{Backhoe Trenç 33}

Length: $4.1 \mathrm{~m}$

Maximum Depth: $1.80 \mathrm{~m}$

Width: $0.65 \mathrm{~m}$

Orientation: North/South

Activities of Recorders: Dimensions were taken, profiles cleaned and examined. No profiles were drawn.

Description of Stratigraphy: Level $]$ is the mixed, redeposited overburden layer, approximately $35 \mathrm{~cm}$ thick, and contains pieces of iron rebar and concrete chunks (possibly from P.0.W. camp). Level 2 is a dark brown (Munsell Color 10 YR 3/3) clayey silt, approximately $90 \mathrm{~cm}$ thick. Level 3 is $30 \mathrm{~cm}$ of light brownish gray (Munsell Color 10 YR 6/2) silty clay. Level 4 is $25 \mathrm{~cm}$ of orange (Munsell Color 5 YR 5/8) clay with occasional gravels.

Materials Recovered: None

Backhoe Trench 34

Length: $4.0 \mathrm{~m}$

Maximum Depth: $1.55 \mathrm{~m}$

Width: $0.65 \mathrm{~m}$

Orientation: North/South

Activities of Recorders: Profiles were cleaned and examined, dimensions taken; and profiles were not drawn.

Description of Stratigraphy: Level 1 is $15 \mathrm{~cm}$ of overburden mixed with original silty loam topsoil. Level 2 is $70 \mathrm{~cm}$ thick and is a dark brownish gray (Munsel 1 
Color 10 YR 4/2) clayey silt. Level 3 is $50 \mathrm{~cm}$ of a 7 ight brownish (Munsel 1 Color 10 YR 6/2) gray silty clay. Level 4 is $15 \mathrm{~cm}$ of orange (Munsell Color 5 YR 5/8) clay.

Materials Recovered: Two round nails were collected.

Backhoe Trench 35

Length: $6.6 \mathrm{~m}$

Maximum Depth: $2 \mathrm{~m}$

Width: $0.65 \mathrm{~m}$

Orientation: East/West

Activities of Recorders: The dimensions were taken, and the profile cleaned and examined. Profiles were not drawn.

Description of Stratigraphy: Leve 1 is $88 \mathrm{~cm}$ of redeposited mixed overburden. Leve 12 is $60 \mathrm{~cm}$ of dark grayish brown (Munse 71 Color 10 YR 4/2) clayey silt. Level 3 is a light grayish brown (Munse11 Color 10 YR 6/2) silty clay. Level 4 is an orange (Munse11 Color 5 YR 5/8) clay with very little gravel content.

Materials Recovered: None

\section{Backhoe Trench 36}

Length: $9.8 \mathrm{~m}$

Maximum Depth: $3.3 \mathrm{~m}$

Width: $0.65 \mathrm{~m}$

Orientation: North/South

Activities of Recorders: The profiles were cleaned and examined (not drawn), and dimensions were taken.

Description of Stratigraphy: Level 1 is $30 \mathrm{~cm}$ of friable dark brownish gray (Munse11 Color 10 YR 4/2) clayey loam. Level 2 is a more compact clay loam, but similar in color to Level 7 ; it is one meter thick and contains occasional smal1 gravels. Level 3 is a blackish gray (Munse11 Color 10 YR $3 / 1$ ) clay soil with a high pebble and cobble content. This layer is approximately $1.8 \mathrm{~m}$ deep. Leve 14 is a $\tan$ (Munsell Color 10 YR 6/4) clay devoid of gravel.

Comments: Although this unit is close to the drainage channel, the amount of alluvial deposition exhibited is striking.

Materials Recovered: Three interior flakes and one .30 caliber she 11 were collected. 
Backhoe Trench 37

Length: $6.15 \mathrm{~m}$

Maximum Depth: $1.75 \mathrm{~m}$

Width: $0.65 \mathrm{~m}$

Orientation: North/South

Activities of Recorders: Dimensions were taken, and profiles were cleaned and examined (not drawn).

Description of Stratigraphy: Leve 1 is a friable loosely compacted grayish brown (Munse]1 Color 10 YR 5/2) silt, approximately $18 \mathrm{~cm}$ thick at the north end and $54 \mathrm{~cm}$.thick at the south end. Level 2 is a gravel lense visible in both walls at the south side, then disappears to the north side $(30-40 \mathrm{~cm}$ thick). Level 3 is a dark brownish gray (Munsell Color 10 YR 4/2) clay, very compact and 60 to $75 \mathrm{~cm}$ thick. Level 4 is a light brown (Munse11 Color 10 YR 6/4) clay, compact and approximately $35 \mathrm{~cm}$ thick. Level 5 is an orange (Munsell color 5 YR 5/8) clay, visible in the bottom $15 \mathrm{~cm}$ of the trench.

Materials Recovered: Materials collected were one horseshoe, three tin can scraps, and one charcoal sample.

Backhoe Trench 38

Length: $4 \mathrm{~m}$

Maximum Depth: $1.3 \mathrm{~m}$

Width: $0.65 \mathrm{~m}$

Orientation: Northwest/Southeast

Activities of Recorders: Profiles were cleaned and examined, but not drawn. Dimensions were recorded.

Description of Stratigraphy: Loosely compacted silt forms Level 1, which is $30 \mathrm{~cm}$ thick. Level 2 is a dark brownish (Munsel1 Color 10 YR 3/3) silty clay, approximately $50 \mathrm{~cm}$ thick. Level 3 is a light grayish brown (Munsell Color 10 YR 6/2) clay, approximately $40 \mathrm{~cm}$ thick. Level 4 is a 1ight gray (Munsel1 Color 10 YR 6/1) clay, visible in the 10 wer $10 \mathrm{~cm}$ of this unit.

Materials Recovered: One chert sample was collected.

Backhoe Trench 39

Length: $3.6 \mathrm{~m}$

Maximum Depth: $0.90 \mathrm{~m}$ 
Width: $0.65 \mathrm{~m}$

Orientation: East/West

Activities of Recorders: Dimensions were taken; profiles were cleaned and examined, but not drawn.

Description of Stratigraphy: Level 1 is a reddish brown (Munsell Color 5 YR 5/6) clayey silt with root disturbances, approximately 35 to $40 \mathrm{~cm}$ thick. Leve 2 is a gravel bed with light reddish brown (Munsell Color 5 YR 5/4) soil content.

Materials Recovered: None

Backhoe Trench 40

Length: $4.25 \mathrm{~m}$

Maximum Depth: $1.25 \mathrm{~m}$

Width: $0.65 \mathrm{~m}$

Orientation: Northeast/Southwest

Activities of Recorders: Dimensions taken; profiles cleaned and examined (not drawn).

Description of Stratigraphy: Leve 1 is $25 \mathrm{~cm}$ thick at the northeast half, and $5 \mathrm{~cm}$ thick in the southwest half. It consists of grayish brown (Munsel1 Color 10 YR 5/2) clay. Level 2 is a fine-grained, homogeneous whitish gray (Munse11 Color 10 YR 6/2) clay.

Materials Recovered: None

Backhoe Trench 41.

Length: $3.8 \mathrm{~m}$

Maximum Depth: $1.35 \mathrm{~m}$

Width: $0.65 \mathrm{~m}$

Orientation: North/South

Activities of Recorders: Profiles cleaned and examined (but not drawn). Dimensions were taken.

Description of Stratigraphy: Level 1 is a loosely compacted, friable, reddish brown (Munsell Color 5 YR $5 / 6$ ) silt $(20 \mathrm{~cm}$ thick). Level 2 is $70 \mathrm{~cm}$ thick and consists of a similar strata as Level 1, except more compact. Level 3 is a pinkish yellow (Munsell Color 7.5 YR 7/6) silty clay, approximately 25-35 cm thick. 
Test Excavations at 41 BX 346

After determining the approximate horizontal extent of the buried prehistoric cultural deposits, a number ( $41 \mathrm{BX} 346$ ) was assigned to the site. It was determined that more controlled data were needed than was possible from backhoe testing. Therefore, it was decided that two $1 \times 2 \mathrm{~m}$ hand-excavated test pits would be placed in the site area. Location of these two test pits (Fig. 1) was determined using the following criteria: (1) amount and kind of cultural debris recovered, and (2) favorable location and elevation where potential for erosion and disturbance would be minimal. The locations of BT24 and BT12, because of their elevation above the low-lying drainage channel and their prehistoric artifact content, were chosen for the test areas.

Test Pit 1, Level 1: ( 0 to $30 \mathrm{~cm}$ below surface)

Fire-Burned and Fractured Stone Count: 2 fragments

Charcoal: present

Total Flake Count: 7

Primary Cortex Flake Count: 2

Secondary Flake Count: 1

Interior Flake Count: 4

Chunks: 2

Other: 1 fragment of a white brick, 3 round nails

Strata: A dark brownish gray (Munse11 Color 10 YR 4/2) friable loamy topsoil with a moderately high gravel content.

Comments: Since evidence of disturbance continued to the bottom of this level, the initial plan for excavating a $20 \mathrm{~cm}$ level was modified to excavate to $30 \mathrm{~cm}$ below surface, where we ran out of cultural debris. Judging from the mixing of artifacts and the gravel content, this is a deflated or eroded stratum.

Test Pit 2, Level 1: (0 to $20 \mathrm{~cm}$ below surface)

Fire-Burned and Fractured Stone Count: 2 fragments

Charcoal: present

Bone: Several fragments of a raccoon skeleton, including vertebrae, cranial fragments, and incisors were collected.

Unifaces: 1 scraper and 1 uniface

Total Flake Count: 29 
Flakes with Edge Modification: 2

Primary Cortex Flake Count: 7

Secondary Cortex Flake Count: 4

Interior Flake Count: 16

Chunks: 0

Round Nails: 2

Square Nails: 2

Bottle Glass: 5 fragments

Historic Ceramics: 2

Other: 1 wooden handle for knife (historic)

Strata: A 1ight brownish gray (Munse11 Color 10 YR 6/2) friable silt with gravel content.

Comments: This level is obviously mixed and disturbed.

Test Pit 2, Level 2: (20 to $30 \mathrm{~cm}$ below surface)

Fire-Burned and Fractured Stone Count: 5 fragments

Charcoal: present

Bone: absent

Unifaces: 1

Total Flake Count: 24

Flakes with Edge Modification: 2

Primary Cortex Flake Count: 7

Secondary Cortex Flake Count: 2

Interior Flake Count: 14

Chunks: 1

Round Nails: 7

Square Nails: 0

Bottle Glass Fragments: 0 
Historic Ceramics: 0

0ther: 1 unidentified piece of rusted metal, 1 bottle cap (post 1930s)

Strata: Same as preceding level.

Comments: Similar to Leve1 1, Level 2 was disturbed and mixed.

Test Pit 2, Level 3: ( 30 to $40 \mathrm{~cm}$ below surface; excavated southeast half only) Fire-Burned and Fractured Stone Count: 1 fragment

Charcoal: present

Bone: absent

Unifaces: 0

Bifaces: 1 thin basal section

Total Flake Count: 20

Flakes with Edge Modification: 1

Primary Cortex Flake Count: 7

Secondary Cortex Flake Count: 3

Interior Flake Count: 10

Chunks: 0

Round Nails: 6

Square Nails: 2

Bottle Glass Fragments: 0

Historic Ceramics: 0

Strata: Same as preceding level.

Comments: Disturbance was present in this level.

Test Pit 2, Level 4: (40 to $50 \mathrm{~cm}$ below surface; excavated southeast half only) Fire-Burned and Fractured Stone Count: 1 fragment

Charcoal: present

Bone: absent 
Unifaces: 1

Total Flake Count: 5

Primary Cortex Flake Count: 1

Secondary Cortex Flake Count: 1

Interior Flake Count: 3

Chunks: 1

Round Nails: 8

Square Nails: 0

Bottle Glass Fragments: 2

Historic Ceramics: 0

Strata: Same as preceding level.

Comments: Amount of prehistoric cultural debris is rare, and this level is also disturbed.

Test Pit 2, Level 5: (50 to $60 \mathrm{~cm}$ below surface; excavated southeast half only)

Fire-Burned and Fractured Stone Count: 0

Charcoa 1: absent

Bone: absent

Unifaces: 0

Total Flake Count: 7

Primary Cortex Flake Count: 2

Secondary Cortex Flake Count: 0

Interior Flake Count: 5

Round Nails: 2

Square Nails: 1

Bottle Glass Fragments: 0

Historic Ceramics: 1 
Strata: Same as preceding level.

Comments: At various places at the bottom of this level rounded pea gravel alluvial deposit was noted. Disturbance continued to the bottom.

Summary of Subsurface Investigations

The subsurface testing investigations confirmed the observations described in The Project Investigations section. Consequently, a buried prehistoric site (41 BX 346) was discovered in an area where it was expected (see Fig. 1). In summary, the study area has been disturbed severely by a variety of processes which can be described as follows:

1. The northwest quarter has been badly disturbed by the construction and subsequent removal of the induction center, P.O.W. buildings, and their associated facilities. The nature of this destruction and disturbance is exhibited in BT33 and BT34.

2. The north central area, where 41 BX 346 is located, has been disturbed probably as a result of natural processes. The fact that no unmixed components were found in Test Pit 1 or Test Pit 2 supports this interpretation. Probably these prehistoric and historic components were mixed as a result of deflation or colluvial erosion or a combination of both. It is possible that military operations at the Post could have contributed to this erosion. An aerial photograph taken in 1928 shows the study area crisscrossed by a network of dirt roads and paths (photograph on file at Fort Sam Houston Military Museum).

3. The northeast and east sides of the study area were thoroughly disturbed. Evidence from BT18, BT19, BT20, BT21, and BT41 shows a very loosely compacted thin topsoil, probably formed by recent colluvial deposition. This suggests that the original land surface was removed. A local anonymous informant recorded that the east side was used for gravel-mining operations about 50 years ago.

4. Subsurface backhoe testing throughout the west side of the study area (BT2, BT3, BT4, BT7, BT10, BT27, BT28, BT29, and others L showed that this area had suffered severe disturbance as a result of being bladed down to subsoil and then used as an area to dump backdirt from the Fort Sam Houston National Cemetery.

\section{RECOMMENDATIONS}

A cultural resource survey was completed in the study area. A prehistoric site (41 BX 346) of unknown function and unknown time depth was discovered during subsurface testing of the area. This site was badly disturbed, probably deflated, and consisted of mixed prehistoric and historic debris. Because of these characteristics, this site is not considered to be a significant cultural resource, nor is it considered to be eligible for the National Register of Historic Places. No other cultural resources of any significance were found in the study area during this survey. No further cultural resource survey work is necessary or recommended. Should potentially significant cultural resources be discovered during subsurface excavations in the study area, a qualified archaeologist and the Texas Historic Preservation Officer should be notified. 


\section{REFERENCES CITED}

Arrow, T.

1959 Ground-Water Geology of Bexar County, Texas. Texas Board of water Engineers, Bulletin 5911.

Black, S. L. and A. J. McGraw

1982 The Panther Springs Site: Cultural Change and Continuity Within the Upper Salado Drainage, South Central Texas. Center for Archaeological Research, The University of Texas at San Antonio, Archaeological Survey Report 100 (in press).

Blair, W. F..

1950 The Biotic Provinces of Texas. Texas Journal of Science 2(1):93-115.

Bryant, V. M., Jr.

1969 Late Full-Glacial and Post Glacial Pollen Analysis of Texas

Sediments. Ph.D. dissertation, The University of Texas at Austin.

Bryant, V. M., Jr. and H. J. Shafer

1977 The Late Quaternary Paleoenvironment of Texas: A Model for the Archeologist. Bulletin of the Texas Archeological Society 48:1-25.

Carr, J. T., Jr.

1967 The Climate and Physiography of Texas. Texas Water Development Board, Repart 53.

Crabtree, D. E.

1972 An Introduction to Flintworking. Occasional Papers of the Idaho State University Museum 28.

Fox, A. A.

1977 An Archaeological Assessment of the San Antonio 201 Wastewater Treatment Project. Center for Archaeological Research. The university of Texas at San Antonio, Archaeological Survey Report 41.

Freese and Nichols, Inc.

1977 Environmental Statement, Overall Mission, Fort Sam Houston, Texas. Department of the Army Headquarters, Forces Command. 
Frkuska, E. C., A. F. Frkuska, F. Valdez, Jr., and T. R. Hester

1977 An Initial Archaeological Assessment of John James Park, City of San Antonio, Texas. Center for Archaeological Research, The university of Texas at San Antonio, Archaeological Survey Report 25.

Gerstle, A., T. C. Kelly, and C. Assad

1978 The Fort Sam Houston Project: An Archaeological and Historical Assessment. Center for Archaeological Research, The University of Texas at San Antonio, Archaeological Survey Report 40.

Gibson, E. C.

1981 Archaeological Investigations in Zavala and Dimmit Counties, Texas: The Internorth Project. Center for Archaeological Research, The University of Texas at San Antonio, Archaeological Survey Report 110 (in press).

Gunn, J. D.

1981 General Coastal Seasonal Dynamics Climatic Model. Manuscript on file; Center for Archaeological Research, The University of Texas at San Antonio.

Hester, T. R.

1980 Digging Into South Texas Prehistory. Corona Press, San Antonio. Hester, T. R., with the collaboration of F. A. Bass, Jr., A. A. Fox, T. C. Kelly, M. F. Chadderdon; and E. S. Harris

1974 Archaeological Survey of Areas Proposed for Modification in the Salado Creek Watershed, Bexar County, Texas. Center for Archaeological Research, The University of Texas at San Antonio, Archaeological Survey Report 3.

Hudson, W. R., Jr., W. M. Lynn, and D. Scurlock

1974 Walker Ranch: An Archeological Reconnaissance and Excavations in Northern Bexar County, Texas. Texas Historical Commission, office of the State Archeologist, Report 26.

Katz, S. R.

1977 An Archaeological Test Excavation at John James Park, City of San Antonio, Texas. Center for Archaeological Research. The University of Texas at San Antonio, Archaeological Survey Report 38. 
McGraw, A. J., F. Valdez, Jr., and I. W. Cox

1977 An Archaeological Survey of Areas Proposed for Modification in the Encino Park Development, Northern Bexar County, Texas. Center for Archaeological Research. The University of Texas at San Antonio, Archaeological Survey Report 39.

01dfield, F. and J. Schoenwetter

1975 Discussion of Pollen-Analytical Evidence. In Late Pleistocene Environments of the Southern High Plains, edited by $F$. Wendorf and J. Hester. Fort Burgwin Research Center, Rancho de Taos, New Mexico.

Robinson, R..L.

1979 Biosilica and Climatic Change at 41 GD 21 and 41 GD 21A. Appendix IV in Archaeological Investigations of Two Prehistoric Sites on the Coleto Creek Drainage, Goliad County, Texas, by D. Fox:102-113. Center for Archaeological Research, The University of Texas at San Antonio, Archaeological Survey Report 69.

Scurlock, D. and W. R. Hudson

1973 An Archeological Investigation of Walker Ranch. Texas Historical Commission, office of the State Archeologist, Special Report 9. Austin, Texas.

Taylor, F. B., R. B. Hailey, and D. L. Richmond

1966 Soil Survey of Bexar County. U.S. Department of Agriculture, Soil conservation Service in Cooperation with the Texas Agricultural Experiment Station, Series 1962(72).

Webb, W. P., ed.

1952 The Handbook of Texas. The Texas State Historical Association, Austin, Texas. 
